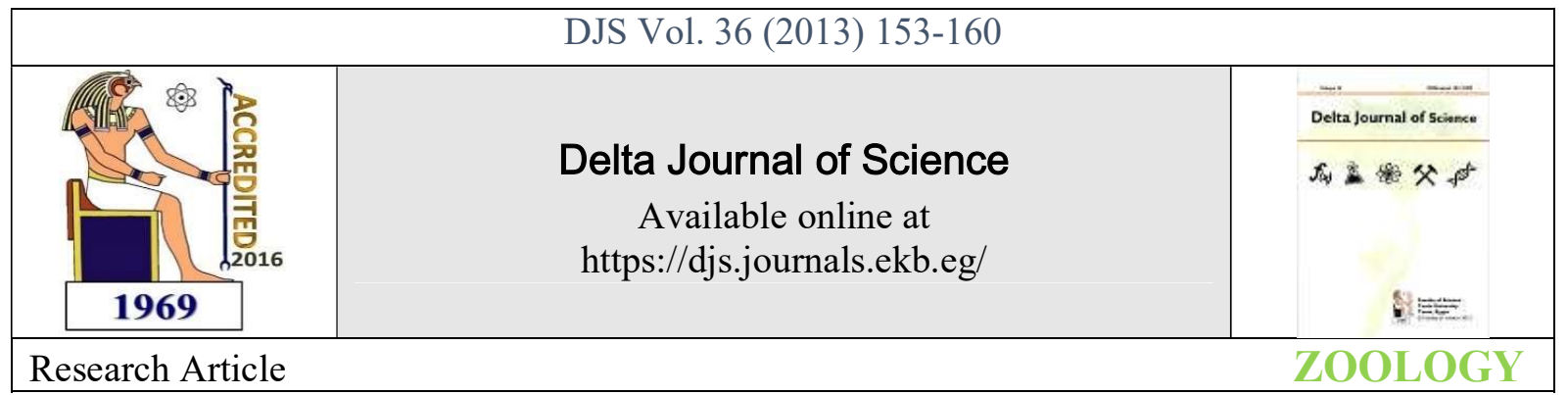

\title{
Isolation of Alpha fetoprotein from colorectal tumor homogenates and optimizing the binding conditions with its ${ }^{125}$ I-antibody
}

\author{
Bilal J.M. Al-Rawi ${ }^{1}$ \\ Sami A. Al-Mudhaffar ${ }^{2}$ \\ Hathama Razooki Hasan ${ }^{2}$ \\ ${ }^{1}$ Chemistry Dept., Education College for women, Al Anbar University \\ ${ }^{2}$ Chemistry Dept., College of Science, University of Baghdad.
}

\begin{abstract}
The aim of this work is to partially purify Alpha fetoprotein (AFP) from homogenates of human colorectal (colon and rectum) tumors. The homogenates used in this work were collected from two patients groups. Group I consists of 13 patients with benign colorectal tumor and group two (II) consists of 21 patients suffering from colorectal cancer. The results revealed that the elution profile gave two peaks by using Sephadex G 200, the first peak with high molecular weight representing the complex and the second peak represents a free antibody.

The optimum conditions of binding of the partially purified AFP with ${ }^{125}$ I-anti AFP antibody were carried out. Protein amounts $\left(25 \mu \mathrm{g} \cdot \mathrm{ml}^{-1}\right)$ for benign and $\left(18 \mu \mathrm{g} \cdot \mathrm{ml}^{-1}\right)$ for malignant, tracer antibody $(1.44 \mathrm{mg} / \mathrm{ml})$ for benign and $(2.16 \mathrm{mg} / \mathrm{ml})$ for malignant group. The optimum $\mathrm{pH}$ was 7.4 for benign and malignant. The optimum time and temperature were $\left(180 \mathrm{~min}\right.$ and $\left.37^{\circ} \mathrm{C}\right)$ for benign and $\left(180 \mathrm{~min}\right.$ and $\left.25^{\circ} \mathrm{C}\right)$ for malignant groups.
\end{abstract}

\section{INTRODUCTION}

Alpha-fetoprotein (AFP) is a glycoprotein with a molecular mass of $68 \mathrm{kDa}$. It consists of a single polypeptide chain and is approximately $4 \%$ carbohydrate. AFP is synthesized in large quantities during embryonic development by the liver. It is one of the major proteins in the fetal circulation, but its maximum concentration is about $10 \%$ that of albumin ${ }^{(1)}$. AFP is a secretory protein with structure and physicochemical properties similar to serum albumin (SA) ${ }^{(2)}$. The main properties of AFP are high affinity for polyunsaturated fatty acids (105 times higher than SA) and ability to bind estrogens. Some data indicate that AFP participates in immune response regulation ${ }^{(2-4)}$.

Different studies confirm that the level of AFP is elevated in tumors of Gastrointestinal Tract (GIT) systems (5). Alpha fetoprotein is found in everyone's blood. Higher levels are found in the blood of pregnant women, fetus, and young children. AFP levels can also elevate in the blood of people with certain diseases and conditions. In adults who are not pregnant, the AFP levels are elevated with certain cancer ${ }^{(6)}$. The normal production of AFP is from liver and yolk sac in fetus but some other tissues produce AFP in cases of tumors like colon, stomach, pancreas ${ }^{(7)}$.
The binding studies of anti AFP antibody with AFP had been carried out ${ }^{(8)}$ with fully optimization of conditions. So we are trying here to examine the optimum conditions of binding reaction after isolation and partially purification of AFP from tumor homogenates as a step for using this protocol for characterization and diagnosing the tumor.

\section{Materials and Methods}

Chemicals:

All chemicals and reagents used in this study were of analar grade and were used without further purification. Bovine Serum Albumin (BSA), Tris (hydroxy methyl amino methane) hydrochloride, EDTA, and Sucrose were obtained from Fluka company, Switzerland. CuSO4.5H2O, Na,K-tartrate , $\mathrm{NaOH}$, $\mathrm{HCl}$, Na2CO3, and Folin - ciocalteaue were obtained from BDH limited pool, U.K. Immunoradiometric assay for AFP was purchased from Immunotech Bechman (France).

\section{Instruments:}

The instruments used in this work: LKB gamma counter type 1270-rack gamma II, Switzerland. Pye-Unicom pH meter, LKB ultracentrifuge type 2332, Cintra 5 UV/visible Spectrophotometer, SM-Shaker,England, PH M62 Standard 
pH meter, Denmark. Sartorius analytical balance BL 210 S, Germany. Memmert water bath, and Memmert incubator.

\section{Patients}

A total of 34 colorectal patients involved in this study with benign and malignant tumors subjected to curative surgery. Their mean age was 49 years ranges (16-66 years). Two groups of colorectal tumor patients were involved in this study; one group with benign colorectal tumors and the other was with malignant.

According to the histopathological examination of the resected pieces, the patients were grouped into the following:

Group (I): Consisted of 13 patients with benign colorectal tumors, the range of their age were (21 -38). Group (II): Consisted of 21 patients with colon and rectum cancer. the range of their age were (41-66).

The patients were admitted for treatment and diagnosis to the following hospitals in Baghdad:

Iraqi College of Medicine, University Hospital, Baghdad Teaching Hospital.AL-Kindy University Hospital, and AlYarmook University Hospital.

Patients with diseases that may interfere with this study were excluded. All surgical operations of malignant and benign tumors were done under the supervision of surgeons:

Dr. Zuhair AL-Bahraini, Dr.Saaeb Sedeq, Dr.Faleh ALAubaidy,

Dr.Abd AL-Salam AL-Tai, and Dr.Ma'ad Medhat.

\section{1- Specimens Collection:}

The specimens were surgically removed from patients of colon and rectum (CR). They were immediately rinsed with ice-cold saline solution, and immersed in the same solution. They were collected and stored at $-20 \mathrm{oC}$ until homogenization. The weight of resected tissue samples range between (1.6-18) gm.

\section{2- Preparation of Tissue Homogenate (9):}

The frozen tissue were washed with ice-cold normal saline and then weighed. The samples were minced, pulverized, with a scalpel scissors in the Petri dish on ice bath, and then homogenized at $4 \mathrm{oC}$ in tris buffer $(0.05 \mathrm{M}, \mathrm{pH} 7.4)$ with ratio of $1: 4$ (weight : volume) using normal homogenizer. The homogenates were filtered through a nylon mesh sieve in order to eliminate fiber connective tissue, and then centrifuged at $4 \mathrm{oC}$. The supernatants and pellets were considered cytosolic and nuclear fractions respectively. The pellet (sediment) was discard, and the cytosolic (supernatant) was used in experiments involved cytosolic cancer antigen AFP source.

Solutions:

TES Buffer solution (0.05M, $\mathrm{pH} 7.4)$ was prepared as follows: $(3.0285 \mathrm{gm})$ of tris (hydroxy methyl amino methane), 0.93060 of Ethylene diamine tetra acetate disodium salt (EDTA) and $(42.7875 \mathrm{gm})$ of sucrose were dissolved in $400 \mathrm{~mL}$ of deionized distilled water, then the $\mathrm{pH}$ was adjusted with $\mathrm{HCl}$ $(1 \mathrm{M})$ at 7.4 and the solution was completed to $500 \mathrm{ml}$ with deionized distilled water.

Protein Determinations:

The method of Lowry (10) was used to determine total proteins in tissue and sera, using bovine serum albumin (BSA) as standard protein.

3- Partial Purification of AFP by Sephadex G 200 Column:
Preparation of The Column:

The dimensions of the column were chosen according to the following equation $(11,12)$ :

\section{Diameter $=\sqrt[3]{\mathrm{m} / 10}$}

Where:

$\mathrm{m}$ : amount of protein in $\mathrm{mg}$.

$\mathrm{L}=30 \mathrm{x}$ diameter

Where

L: length of column.

Preparation of The Buffer:

Tris buffer $(0.05 \mathrm{M})$ was prepared by dissolving $3.0285 \mathrm{gm}$ of tris (hydroxy methyl amino methane, 0.9306 gm of EDTA and $0.1 \mathrm{gm}$ of sodium azide in $400 \mathrm{ml}$, the volume was completed to $500 \mathrm{ml}$ with deionized distilled water, the $\mathrm{pH}$ was adjusted to 7.2 .

Preparation of Gel:

The gel was prepared by allowing the preswollen gel to swell again in tris buffer $\mathrm{pH} 7.2$, then left to settle and the excess of buffer was decanted. The step was repeated several times. Suction was then used to degas the gel then the slurry was left for $24 \mathrm{hrs}$. to equilibrate with buffer.

The swollen gel was suspended and carefully poured into vertical glass column $(0.9 \times 27)$ down the wall using a glass rod. After the gel had settled the column was equilibrated with this buffer for $72 \mathrm{hrs}$.

\section{4- Determination of The Void Volume:}

The void volume of the column was determined using blue dextran 2000 at concentration of $2 \mathrm{mg} \cdot \mathrm{ml}-1$ dissolving in tris buffer $\mathrm{pH} 7.2$, the elution was carried out with the same buffer at a flow rate of $10 \mathrm{ml} . \mathrm{hr}-1$. Fractions of $1 \mathrm{ml}$ were collected and their absorbance was measured at $600 \mathrm{~nm}$.

\section{5- Purification Procedure:}

Reagents:

Tris buffer $\mathrm{pH}$ (7.2) contained $0.02 \%$ sodium azide was prepared as described previously in experiment (Preparation of the buffer).

Procedure:

The sample of tissue homogenate $(720 \mu \mathrm{l})$ of colon and benign tumor containing approximately $(8 \mathrm{mg})$ proteins was applied to the surface of the gel. The elution was carried out using tris buffer (pH7.2) with a flow rate of $10 \mathrm{ml} . \mathrm{hr}-1$, and fraction of one (ml) was collected, the elution was made at room temperature.

\section{Calculations:}

In each fraction, the protein concentration was determined using the absorbance in UV region at $280 \mathrm{~nm}$, then the accurate protein concentration was determined according to Lowry method (10). The total binding of each fraction was estimated using the optimum condition of crud homogenate which had been got previously (9). The binding of each fraction was calculated and plotted against the elution volume. The specific binding activity percent was estimated from the following equation: 


\section{Specific binding activity $=\frac{\text { Total binding } B / T}{\mathrm{mg} \text { of protein }} \times 100$}

\section{6- Dialysis for Concentration}

After preparing a dialysis tube, the fraction that contained high levels of the binding activity were collected, pooled, and concentrated by dialyzing against sucrose at $4 \mathrm{oC}$ for 2 hours, to obtain the required concentration to be used in the next experiments.

7- The Choice of Optimum Conditions For The Binding of The Partial Purified AFP To 125IAnti AFP Antibody:

The Choice of The Optimum Protein Concentration:

1. A volume of $40 \mu \mathrm{l}$ of $125 \mathrm{I}$-anti AFP Antibody ( 2.38 mg.ml-1) was added to increasing amounts $(5,10$, $15,20,25$ and $30 \mu \mathrm{g} . \mathrm{ml}-1)$ of a pooled fractions under the first peak of the partial purified colon cancer and $(9,18,27,36,45$ and $54 \mu \mathrm{g} . \mathrm{ml}-1)$ of a pooled fractions under the first peak of benign colorectal tumor, the volume was completed to 250 $\mu \mathrm{l}$ with $0.05 \mathrm{M}$ of tris buffer $\mathrm{pH} 7.8$.

2. All tubes was incubated for 4 hours at $25^{\circ} \mathrm{C}$.

3. Two additional tubes containing $40 \mu \mathrm{l}(2.38 \mathrm{mg} . \mathrm{ml}-$ 1) of 125I-anti AFP Antibody only for total activity were set-aside until counting.

4. After incubation, the tubes were centrifuged at 4000r.p.m for one hour at $4 \mathrm{oC}$ using cooling centrifuge.

5. The supernatant was decanted and the radioactivity of the complex formed was counted.

6. The $(B / T) \%$ was calculated as described previously, then was plotted against protein concentration.

\section{Solutions:}

This buffer $(0.05 \mathrm{M})$ was prepared by dissolving $0.6057 \mathrm{gm}$ of tris (hydroxy methyl amino methan in $50 \mathrm{ml}$ of distilled water and the $\mathrm{pH}$ was adjusted with $\mathrm{HCl}(1 \mathrm{ml})$ at $\mathrm{pH}(7.8)$. The volume was completed to $100 \mathrm{ml}$ with distilled water.

\section{The Effect of 125I-anti AFP Antibody:}

1. Increasing volume of 125I-anti AFP Antibody (10, $20,30,40,50$, and $60 \mu \mathrm{l})$ containing $(0.720,1.44$, $2.16, \quad 2.88, \quad 3.60$ and 4.32 mg.ml-1) was incubated with 25 and $18 \mu \mathrm{g} . \mathrm{ml}-1$ of partially purified AFP for the benign case and malignant respectively, the volume was completed to $250 \mu \mathrm{l}$ with $0.05 \mathrm{M}$ tris buffer $\mathrm{pH} 7.8$.

2. All tubes were incubated for $180 \mathrm{~min}$ at $25^{\circ} \mathrm{C}$.

3. After incubation, the tubes were centrifuged at 4000r.p.m for one hour at $4 \mathrm{oC}$ using cooling centrifuge.

4. The supernatant was decanted and the radioactivity of the complex formed was counted.

5. The $(B / T) \%$ was calculated as described previously, then was plotted versus 125I-anti AFP antibody concentration.

\section{The Choice of Optimum pH:}

1. To choice the optimum $\mathrm{pH}$ for the partially purified AFP from colon colorectal tumor homogenate

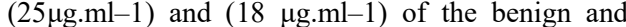
malignant of partially purified AFP were incubated with $(30,20 \mu \mathrm{l})(2.16,1.44 \mathrm{mg} \cdot \mathrm{ml}-1)$ respectively of 125I-anti AFP Antibody. The volume of all tubes was completed to $250 \mu \mathrm{l}$ with tris buffer $(0.05 \mathrm{M})$ of different $\mathrm{pH}(6.8-8.0)$.

2. All tubes were incubated for $180 \mathrm{~min}$ at $25^{\circ} \mathrm{C}$.

3. After incubation, the tubes were centrifuged at 4000r.p.m for one hour at $4 \mathrm{oC}$ using cooling centrifuge.

4. The supernatant was decanted and the radioactivity of the complex formed was counted.

5. The $(\mathrm{B} / \mathrm{T}) \%$ was calculated as described previously, then was plotted against the corresponding $\mathrm{pH}$.

\section{The Time Course of Partially Purified AFP:}

1. To determine the time course of the partially purified AFP from colorectal tumor homogenate, 25 $\mu \mathrm{g} . \mathrm{ml}-1$ protein of the benign case of partially purified AFP was incubated with $30 \mu \mathrm{l}$ of $125 \mathrm{I}$-anti AFP Antibody, while $18 \mu \mathrm{g} . \mathrm{ml}-1$ protein of the malignant case of the partially purified AFP was incubated with $20 \mu \mathrm{l}$ of 125I-anti AFP Antibody, the volume was completed to $250 \mu \mathrm{l}$ with tris buffer (0.05M, pH 7.4).

2. All tubes were incubated at $25^{\circ} \mathrm{C}$ at different time intervals $(1,2,3,4,5,6,7,8,9$, and 10) hours.

3. To determine the time course of the two groups of partially purified AFP at different temperature, steps 1,2 in the same experiment were repeated at different temperature $\left(4,37\right.$ and $\left.45^{\circ} \mathrm{C}\right)$

4. After incubation, the tubes were centrifuged at 4000r.p.m for one hour at $4 \mathrm{oC}$ using cooling centrifuge.

5. The supernatant was decanted and the radioactivity of the complex formed was counted.

6. The $(\mathrm{B} / \mathrm{T}) \%$ was calculated as described previously, then was plotted against the time at different temperature.

7. The concentration of (125I-anti AFP / AFP) complex formed after time $t$ was calculated from the following equation:

\footnotetext{
${ }^{125} I$ - anti $\mathrm{AFP} / \mathrm{AFP}=\frac{\text { count (c.p.m) of }{ }^{125} I \text { - anti AFP specificaly bound after time }(\mathrm{t})}{\text { Total counts }\left(\text { c.p.m) of }{ }^{125} I \text { - anti AFP used in theincubation }\right.} \mathrm{X}^{125} \mathrm{I}$ - anti AFP
} in $\mathrm{mg}^{\mathrm{ml}} \mathrm{l}^{-1}$ after time $(\mathrm{t})$

\section{RESULTS and Discussion}

Partial Purification of AFP:

Isolation of cytosol AFP antigens was performed by gel exclusion chromatography technique. Colorectal tumor homogenate was applied to Sephadex G $200(0.9 \times 27 \mathrm{~cm})$. Figure (1) shows the elution profile of blue dextran 2000.The volume of the buffer required to elut the blue dextran, which represents the void volume, was $(10 \mathrm{ml})$. The use of blue dextran is because the high molecular weight $(2000 \mathrm{KDa})$ to make sure that the gel packing is suitable for isolation different protein from each other's depending on the difference in molecular weight ${ }^{(13)}$.

The elution profile of AFP from malignant colorectal tumor and benign was illustrated in figure (2). The resultant fraction 
of the homogenate were collected, polled and detected for the binding with ${ }^{125}$ I-anti AFP Antibody. All trials of gel filtration revealed two peaks profile. The first peak represents $\left({ }^{125} \mathrm{I}-\right.$ anti AFP antibody / AFP) complex, while the second peak represents unbound (free) ${ }^{125} \mathrm{I}$-anti AFP antibody. The difference in molecular weight is the principle of isolation in gel filtration and depend on the exclusion. So the first peak is for the complex of AFP with its antibody which have high mass comparing with AFP which has the second peak. The binding method in ImmunoRadioMetricAssaay IRMA is highly specific and highly sensitive because it established on the immune reaction and monitored by estimating the radioactivity ${ }^{(14)}$. Accordingly, only two peaks had been got.

The Choice of the Optimum Conditions For The Binding of Partially Purified AFP with ${ }^{125}$ I-anti AFP Antibody:

\section{The Choice of the Optimum Protein Concentration:}

Figure (3) shows the optimum protein concentration for the isolated AFP of the malignant and benign colorectal tumor homogenate. This experiment was carried out by adding increasing amounts of the isolated forms to fixed amounts of ${ }^{125}$ I-Antibody to produce ( ${ }^{125} \mathrm{I}$-anti AFP Antibody/ AFP) complex. The maximum binding occurred at $25 \mu \mathrm{g} \cdot \mathrm{ml}^{-1}$ for (benign) isolated form, while $18 \mu \mathrm{g} \cdot \mathrm{ml}^{-1}$ was the optimum protein concentration for the binding of (malignant) isolated form. Further additions of AFP gave rise to solubilization of complex formed ${ }^{(15)}$. The excess of added antigen, which is represented by excess of protein, gives small chance to make a lattice between antibody and antigen ${ }^{(16)}$. The difference in results between two types of tumor homogenates gave different results because the whole environment is different (17).

The decrease in the binding after reaching the maximum binding may be due to the solubilization of the complex formed by the excess of AFP added ${ }^{(18)}$, or may be due to the conformational changes in AFP and ${ }^{125}$ I-anti AFP Antibody rather than the formation of reversible inactive $\left({ }^{125} \mathrm{I}-\right.$ anti AFP Antibody / AFP) complex (19), another auther reported that when the precipitation of the complex out of the solution, due to the multivalent nature of both molecules (20). The radioactive antibody has two binding sites, it can cross link antigenic sites of two different AFP molecules and can form maximum amount of the complex and therefore maximum precipitate will occur ${ }^{(20)}$.

\section{The Effect of ${ }^{125}$ I-anti AFP Antibody:}

The effect of ${ }^{125} \mathrm{I}$ - anti AFP Antibody concentration on the binding with isolated forms of the benign and malignant colorectal homogenate is shown in figure (4).

The maximum binding obtained at $2.16 \mathrm{mg} . \mathrm{ml}-1$ for (malignant) and $1.44 \mathrm{mg} \cdot \mathrm{ml}^{-1}$ for (benign). It was found that the amount of ${ }^{125} \mathrm{I}$ - anti AFP Antibody required to bind with their isolated Antigen forms is less than in crude homogenate (8). This may be due to the increment of the epitop (the part of an antigen molecule that binds to any single antigen combining site) $)^{(21)}$.

The binding increased when labeled antibody increased, then the binding percent decreased as the amount of ${ }^{125}$ I-anti AFP antibody increased. The reason is due to the all-antigenic sites covered with antibody and the complex formation is inhibited (22). These results indicate that the binding is principally dependent on the amount of the antibody in the reaction mixture ${ }^{(23)}$, because one of the factors affecting the binding percent of Antibody - Antigen reaction is the concentration of the Antibody. According to the results of this experiment, the above concentrations of ${ }^{125}$ I-anti AFP antibody were used in the subsequent experiments.

In spite of the specificity of IRMA technique, there is a difference between the crude homogenates binding and partially purified AFP binding. That is because the proteinprotein interaction is affected by the vicinity of high protein concentration ${ }^{(24,25)}$.

\section{The Choice of The Optimum pH:}

In order to choice the optimum pH $25 \mu \mathrm{g} \cdot \mathrm{ml}^{-1}$ and $18 \mu \mathrm{g} \cdot \mathrm{ml}^{-1}$ for (benign, malignant) respectively of the two isolated forms of the colorectal tumor homogenate were incubated with 2.16,1.44 mg. $\mathrm{ml}^{-1}$ of ${ }^{125} \mathrm{I}$-anti AFP antibody respectively. Figure (5) shows the optimum $\mathrm{pH}$ of the two isolated antigens forms. The results revealed that the optimum $\mathrm{pH}$ for both isolated antigens binding to its antibody was 7.4. The similarity in $\mathrm{pH}$ (7.4) suggests that the AFP isolated forms possess the same epitopes in both cases. That means the induction of protonation - deprotonation process occurs with the same changed polar groups on the amino acid residues present in the binding domain ${ }^{(26,27)}$.

\section{The Time Course of Partial Purification AFP:}

Figure (6) and (7) illustrate the time course of the binding of isolated antigen from malignant and benign colorectal tumor homogenate to their antibody. The malignant antigen binds to its antibody in highest state after 3 hours at $25^{\circ} \mathrm{C}$, while benign Antigen binds after 3 hours at $37^{\circ} \mathrm{C}$.

The binding of ${ }^{125} \mathrm{I}$ - anti AFP Antibody to its Antigen is a time and temperature dependent process ${ }^{(28)}$. The decrease of the binding may be due to either the degradation of AFP or irreversible dissociation of the ( ${ }^{125} \mathrm{I}$-anti AFP Antibody / AFP) complex. At higher temperatures, denaturation and destruction tertiary structure may occur leading to loss of activity and conformational changes. At lower temperature, heat is not enough to overcome the energy barrier, even for the catalyzed reaction (29). Heating more than $45^{\circ} \mathrm{C}$ disrupt the folded structure of the protein by increasing the vibrational motions of atoms ${ }^{(30,31)}$.

\section{References}

Burtis C. A.; Ashwood E. R.; Bruns D. E.; (2008), "TIETZ Fundamental of clinical chemistry", 6th ed., Saunders Elsevier, USA. p 350.

Lazarevich N. L. ;(2000) Molecular mechanisms of AlphaFetoprotein gene expression. BIOCHEMISTRY(Moscow) 65(1): 139-153.

Deutsch, H. F. (1991), Chemistry and biology of alphafetoprotein. Adv. Cancer Res., 56, 253-312.

Abelev, G. I. (1993), Alpha fetoprotein biology. Sov. Sci. Rev. D. Physicochem. Biol., 11, 85-109.

Haisma, H. J.; Battaile A.; Stradtman E. W.; Knapp. R. C.; Zurawski V. R.; (1987). In. J. Cancer. , 40: 758-762.

Ursula, T.; and Pentti, L.; (1990). Interference of human anti mouse antibody in CA 125 assay after immunoscintigraphy: anti - idiotypic antibodies not neutralized by mouse IgG but removed by chromatography. Clin. Chem., 36 (7): 1333-1338. 
Sell S. (1991). Cancer markers. In: Moossa AR Schempff SC, Robson MC, eds. "Comprehensive textbook of oncology", 2nd ed., vol 1, Baltimore: Williams \&Wilkins, pp 225-38.

Al - Rawi B. J.; (2008). "Biochemical studies on Alphafeto protein in Human Colorectal Tumor Homogenates". Ph. D Thesis Supervised by Al - Mudhaffar S. A.; College of Science, Baghdad Univ.

Fowler SL, McLean AC, Bennett SAL (2009) Tissue--specific cross--reactivity of connexin 32 antibodies: Problems and solutions unique to the central nervous system. Cell Commun Adhes, 16:117--130

Lowry, O. H.; Farr, L.; Randell, R.; Rosebrough N. J. ; ( 1951 ). Protein measurement with the folin phenol reagent. J. Biol. Chem., 193: 265.

Blume, K.G., Biochim. Biophys. Acta, 227, 364 (1971).

Swart, A.C.W. and Hemker, H.C., Biochim. Biophys. Acta, 222, 692 (1970).

Skoog, D. A.; Principles of Instrumental Analysis, 6th ed.; Thompson Brooks/Cole: Belmont, CA, 2006, Chapter 28.

Tedder T F and Hoffmann E M, (1981); Immunoradiometric assay for examination and quantitation of Brucella abortus-specific antibodies reactive with the antigen(s) used in the indirect hemolysis test. J Clin Microbiol. 14(4): 415-426.

Al - Rubae 'I, S. H.; (2002). "Biochemical Characterization of CA $15-3$ in Sera and Tissues of Breast Tumors". Ph. D Thesis Supervised by Al - Mudhaffar S. A.; College of Science, Al - Mustansiriyah Univ.

Friefelder D.; Physical Biochemistry, Application to Biochemistry, Molecular Biology; 2nd ed., San Fracisco; W. H. Freeman \& Company; 1982; chapter 14: pp. 494-591.

Jang JH, Balik E, Kirchoff D, Tromp W, Kumar A, Grieco M, Feingold DL, Cekic V, Njoh L, Whelan RL.(2012); Oncologic colorectal resection, not advanced endoscopic polypectomy, is the best treatment for large dysplastic adenomas. J Gastrointest Surg. 16(1):165-71

Roitt, I.; Brostoff, J.; Male, D.; (1998) "Immunology"; 5th ed.; London Mosby Philadelphia st. Louis;USA.

Changux, J. P.; (1966). Responces of acetylcholinesterase from Torpedo marmorata to salts and curarizing drugs. Mol. Pharmacol. ;. ; 2 : 369- 392.

Bryant, N. J.; (1986). "Laboratory Immunology and Serology" 2. nd. ed, Philadelphia, W. B. Saunders Co. Chap. 5. pp. $49-$ 52.

Brostoff, J.; and Male, D.; (1994). "Clinical Immunology, an Illustrated Outline”. Philadelphia., Mosby., Chap. 8, pp. 112.

Helen, C.; Mansel, H.; Siraj, M.; Neil, S.; (1999). "Essential of Clinical Immunology". 4 th. ed., U .K., Blackwell Science Ltd., Chap. 19 pp. 314 - 321.

Dadliker, W. B.; and Satussure, V. A.;(1970). Fluoroscence polarizing in immunochemistry. Immunochem.; 7: 799-828.

Xenarios I, Rice DW, Salwinski L, Baron MK, Marcotte EM, Eisenberg D (2000). "DIP: the database of interacting proteins". Nucleic Acids Res. 28 (1): 289 91.
De Las Rivas J, Fontanillo C (2010). "Protein-protein interactions essentials: key concepts to building and analyzing interactome networks". PLoS Comput Biol 6 (6): e1000807

Shiu, R. P. C.; Friesen, H. G.; J. Biol. Chem.; 1974; 249: 7902.

Cabra V, Arreguin R, Vazquez-Duhalt R, Farres A. (2006); Effect of temperature and $\mathrm{pH}$ on the secondary structure and processes of oligomerization of 19 $\mathrm{kDa}$ alpha-zein. Biochim Biophys Acta. 1764(6):1110-8.

Al - Kazzaz, F. F.; (2000). "Molecular Characterization of Carcinoembryonic Antigen (CEA) in Some Colorectal Tumors”. Ph. DThesis Supervised by Al - Mudhaffar S. A.; College of Science, $\mathrm{Al}$ - Mustansiriyah Univ.

Devilin, T. M.; (1986) "Text Book of Biochemistry with Clinical Correlation”. 2 nd. ed., New York, Inc., John Wily and Sons. , pp 273.

Price, N .C.; and Stevens, L. (1989); "Fundamentals of Enzymology". 2 nd. ed. New York, Oxford University Press. , pp. 125.

George N. Somero, (1995); protein and temperature,Annual Review of Physiology, Vol. 57: 43-68. 


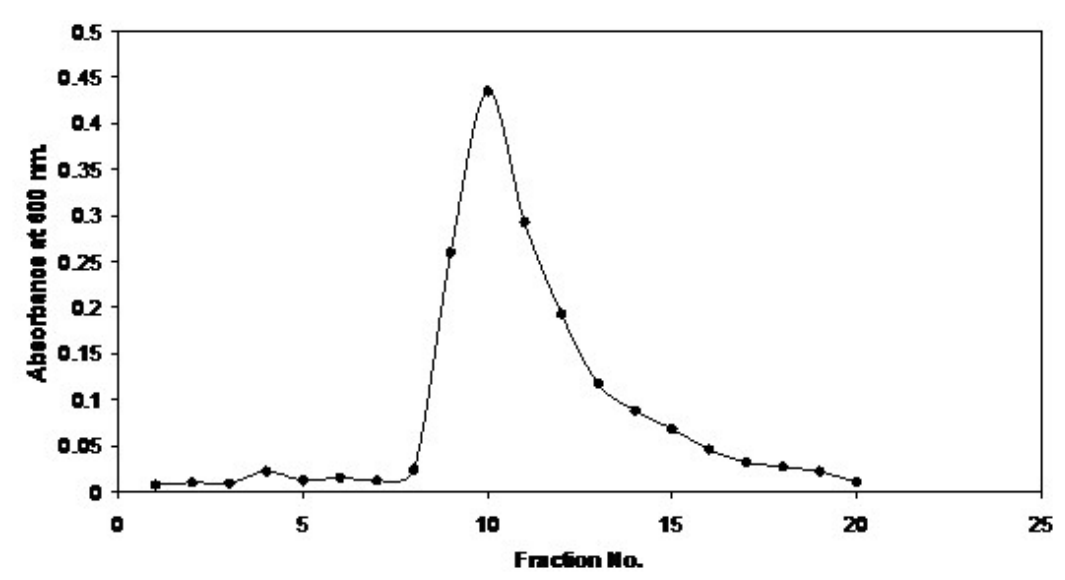

Figure (1): The elution of blue dextran 2000.

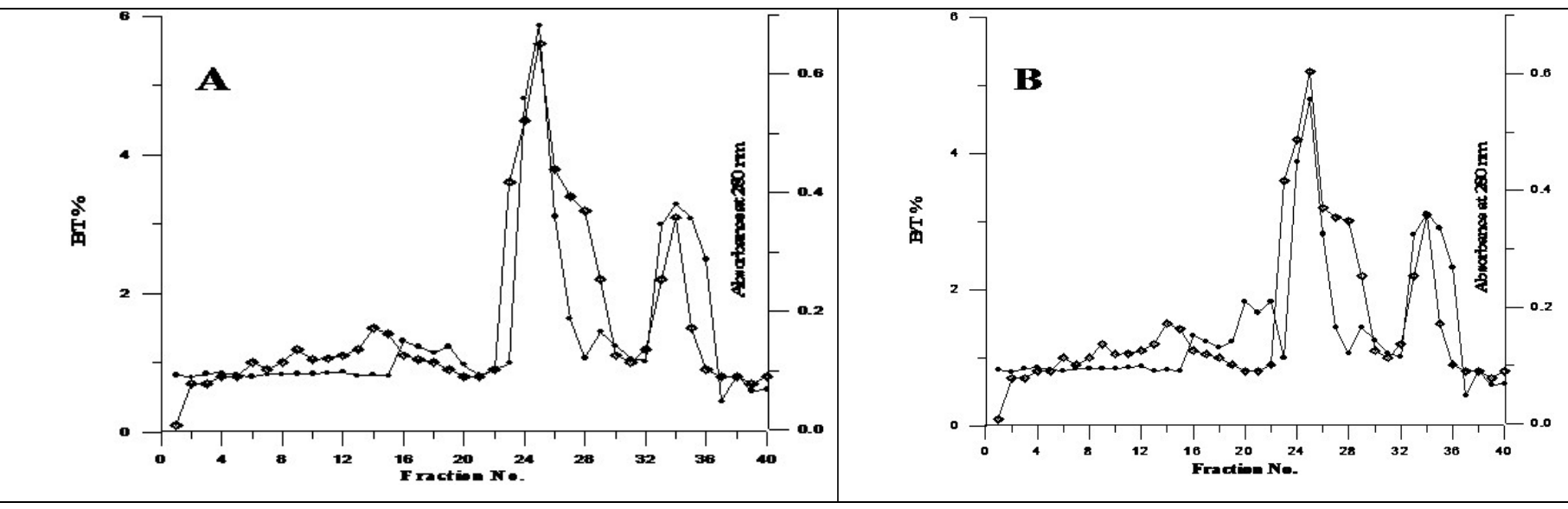

Figure (2): The elution profile of Human AFP ‘(.) means absorbance and ( $\diamond)$ means B/T\%’. (A) Benign colorectal tumor, (B) Malignant colorectal tumor 


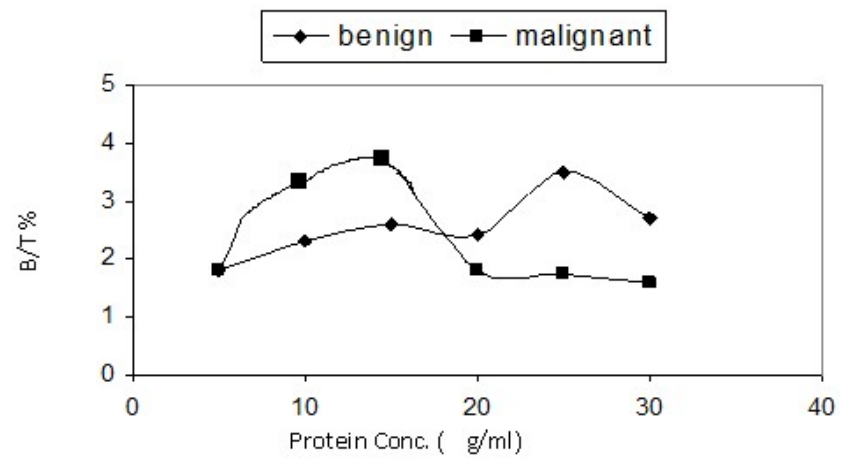

Figure (3) :Influence of Protein Concentration on the binding of ${ }^{125}$ I-anti AFP Antibody with partially purified AFP from Colorectal tumor homogenate.

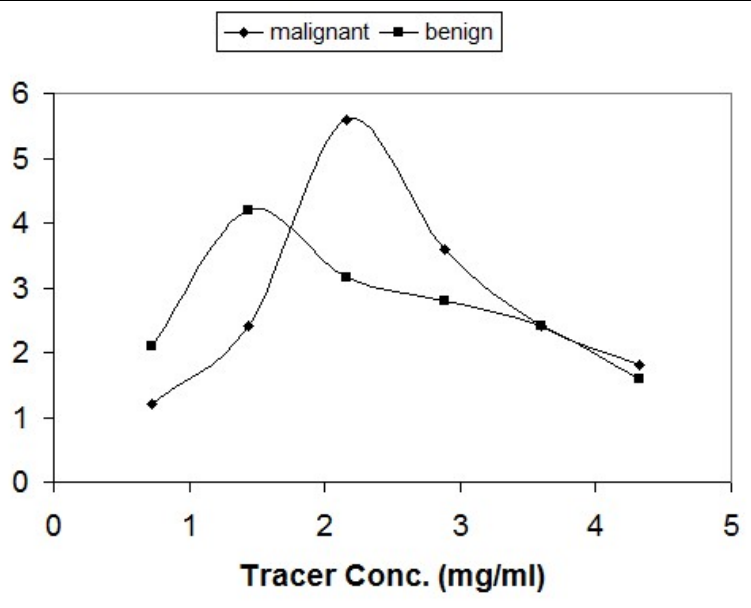

Figure (4): Effect of ${ }^{125}$ I-anti AFP Antibody concentration on the binding with partially purified AFP from Colorectal tumor homogenates.

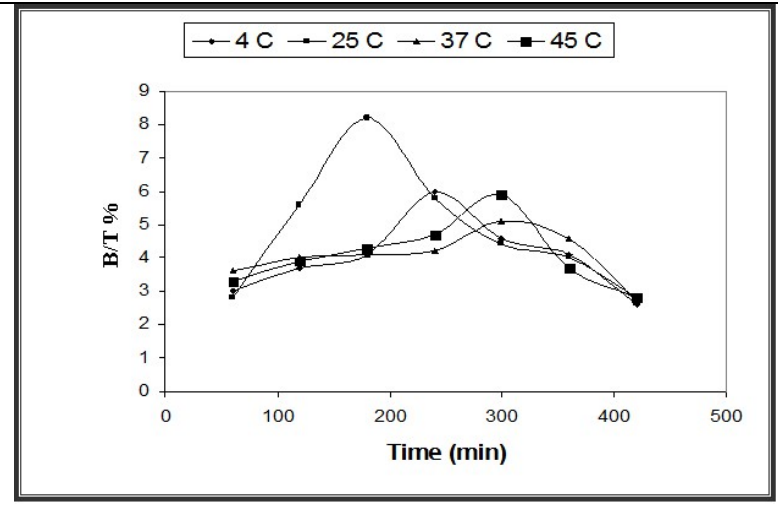

Figure (6): Time - Course of ${ }^{125}$ I-anti AFP binding to partially purified (malignant) Antigen from Colon Cancer.

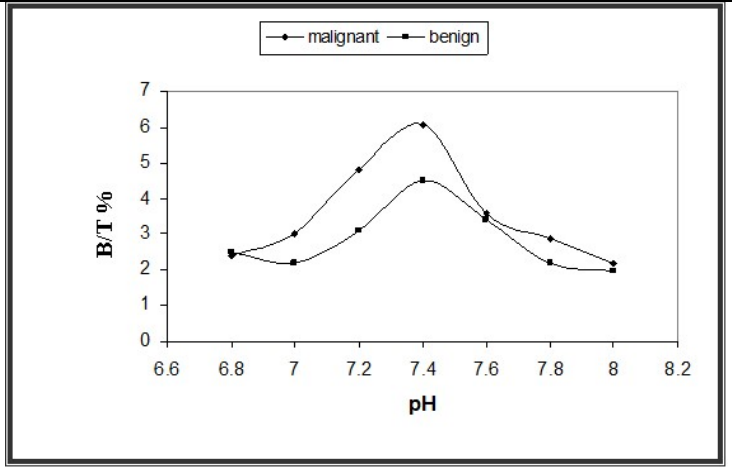

Figure (5): $\mathrm{pH}$ effect on the binding of ${ }^{125} \mathrm{I}-$ anti AFP Antibody with partially purified AFP from Colorectal tumor homogenates.

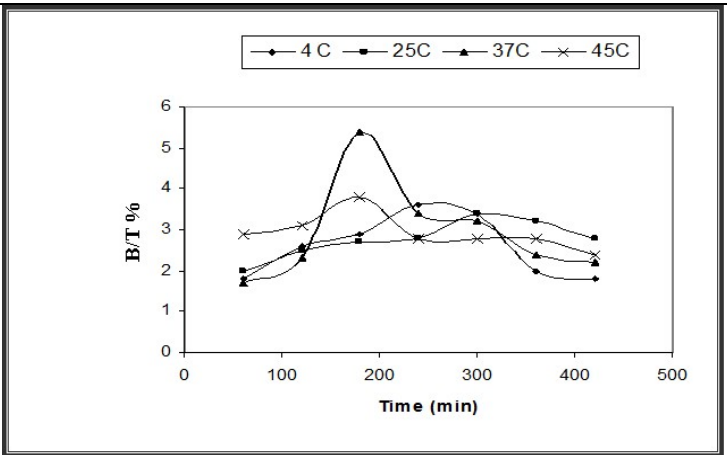

Figure (7): Time - Course of ${ }^{125}$ I-anti AFP binding to partially Purified (benign) Antigen from Colorectal tumor. 


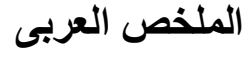 \\ عزل البروتين الجنيني الفا من مجانسات اورام القولون والمستقيم وضبط الظروف المثلى لارتباطه مع مضاده المعلم بنظير اليود المشع المعان 125}

$$
\begin{aligned}
& \text { بلال جاسر محمد الراوي1 } \\
& 1 \text { قسم الكيمباء، كلية التربية للبنات / جامعة الانبار } \\
& 2 \text { قسم الكيمياء، كلية العلوم / جامعة بغداد }
\end{aligned}
$$

يهدف البحث الى عزل البروتين الجنيني الفا (AFP) وتتقيته جزئياً من مجانسات اورام القولون والمستقيم البشرية. استخدت مجمو عتين من المرضى اذ تمت مقارنة النتائج فيما بينهما. شملت المجموعة الاولى 13 مريضاً مصاباً باور ام القولون والمستقيم الحميدة بينما ضمت المجموعة الثانية 21 مريضاً مصاباً باورام القولون و المستقيم الخبيثة. دلت نتائج الفصل وجود قمتين عند استخدام هلام السيفاديكس (G 200)، اذ تدل القمة الاولى للمركب الاعلى وزنا وهو المعقد ما بين جزئية (AFP) والجسم المضاد المعلم باليود المشع 125 ،امـا القمة الثانية فعائديتها لجزيئة الجسم المضاد للبروتين الجنيني الفا المعلم باليود المشع 125 الحر غير المرتبط.

اجريت دراسات ضبط الظروف المثلى لارتباط البروتين الجنيني الفا مع ضده المعلم بالاشعاع، واتضح بان تركيز البروتين الامثل هو (25) مايكرو غر ام لكل ملليلتر للاور ام الحميدة و(18) مايكرو غر ام لكل ملليلتر للور ام الخبيثة. بينما كان تركيز المضاد المعلم باليود المشع 125 (1.44) مليغر ام لكل ملليلتر للورام الحميدة بينما (2.16) مليغر ام لكل ملليلتر للورام الخبيثة. درجة حامضية المحلول المثلى كانت 7.4 لكلا الحالتين. الزمن الامثل لفترة الحضن كانت 180 دقيقة لكلا الحالتين امادرجة الحرارة المثلى فهي 37 درجة مئوية للاورام الحميدة و25 درجة مئوية للاور ام الخبيثة. 